\title{
THE ROLE OF THE CHURCH IN THE LAND DEBATE
}

\author{
Kelebogile Thomas Resane \\ Department of Historical and Constructive Theology \\ University of the Free State
}

\begin{abstract}
The issue of land is emotive and controversial. The colonisers allotted themselves land ignoring the African emotional and religious attachment to land. Churches ended up owning tracts of land from which original inhabitants had been mercilessly removed. Landlessness has become a mark of various population settlement patterns. The church is called on to be prophetic by partnering with victims for land re-allocation. The paper suggests four decisive steps that the church should take. These are firstly to advocate strategies to clarify, and secondly to entrench rights for the victims - bilateral agreements - with which the church is conversant with current policies regarding land in order to assist the dispossessed. Thirdly, to reach degrees of consensus which may contribute to amicable settlement of disputes that satisfy both parties and where majority decisions are respected. Finally, the church should promote dialogue, where dissenting parties should synergise towards a unified action to address the situation; or clarify any misunderstanding.
\end{abstract}

Key words: Land; Church; Landlessness; Victims; Allocation; People

Land debates and disputes have a long and complex history in South Africa. Louis Changuion and Bertus Steenkamp (2012) outline the evolutionary processes of land tenure from 1671 to 2011. In an article by Chris Maxon (2018:3) in the City Press newspaper of 3 June, 2018, he notes that:

The debate needs a radical shift and must be taken further by progressive forces to give it completeness by succinctly detailing a programmatic approach to meaningful land expropriation.

Land has become an emotive issue in postcolonial Africa, and for the Republic of South Africa, the emotiveness is inflated more than anywhere else. Land has become the focus of constant struggle between the forces of dispossession, greed, exploitation and landgrabbing (Wright 2004:81). This is simply because humans, especially in Africa, develop some form of emotional attachment to the land. Oil is added to this fire by the failure of or slow response to land restitution or redistribution processes. This cry is highlighted by Mbatha (2017:1), who says that "More failures than successes in reform projects have been reported since 1994".

In 1997, Takatso Mofokeng published a moving chapter in a book edited by Guma titled: An African Challenge to the Church in the 21st Century. The chapter is titled: "Land is our mother: A Black Theology of Land". The metaphor "mother" in the article is loaded with symbolism of the mother so emotionally attached to the child, to the 
degree that she would even sacrifice her life to save the child. It is expressed in my language by the proverb: Mmangwana o tshwara thipa ka fa bogaleng (a mother defends the child by staving off the sharp blade or knife by her own hand). According to Vuyani Vellem (2016:1), "Land is an integral part of the whole constellation of life, which cannot be separated into dichotomized compartments or spheres in the African ethical view of life". This is also emphasised by Ilgunas (2018:213):

Ecosystems are made up of complex, interdependent relationships between environments and the organisms that live within those environments. When someone who doesn't understand the land's ecology manages the land, then the ecosystem and all of its inhabitants become threatened.

This is the root source of the problem when the colonisers allotted themselves land as a commodity. They were ignorant of African human-ecosystem interdependence; and as a result seared the very depth of African emotional relations with the land.

Historically, the church has been divided also on the issue of the land. This is due to the reality that the church includes members of the colonisers and the colonised. Mainline Christianity to a certain degree joined the civil government in dispossessing people of their land. Some Christian denominations still own land that was given to them by the government after forced removals of the population, while mission stations acquired title deeds or were compensated for new developments on the land.

\section{The current reality}

Until 1994, land ownership was characterised by an embarrassing imbalance whereby only $13 \%$ of the land was occupied by the majority black population, and $87 \%$ owned either by the white minority or the apartheid government. After 1994, when many restrictive apartheid laws were repealed, the reality came to the surface. Mushrooming informal settlements, uncontrolled movement of people to the margins of cities, and the swelling of rural settlements bear testimony to landlessness. Apartheid laws suppressed this reality by controlling the movements of population. Ramantswana (2017:79) paints a vivid picture of such landlessness:

Landlessness is not an invisible characteristic of our society in the so-called postcolonial, post-apartheid South Africa, unless one chooses to ignore it or turn a blind eye. Landlessness is apparent in the townships where the black masses have to share the limited space by opening up rooms for rental, building back rooms or erecting shacks in the yard as a means of survival and a means of accommodation for the landless. Landlessness is also a visible reality in and around South African cities.

The reality of landlessness has become visible to the naked eye, regardless of settlement patterns. It has become a characteristic of the human landscape in South Africa. Ramantswana (2017:79) continues to drive the reality of landlessness:

The landlessness of the black masses is evidenced by the continuous mushrooming of informal settlements... To be landless in South African cities is to live in canals, 
under bridges, under trees, in parks, and in open spaces in front of buildings or shops. Even worse, to be a landless female is to be prey to slave-traders and sextraders and to be first in line for endless rape. Landlessness sets up our people for dehumanization and exploitation.

To these phenomena cited by Ramantswana, one can add the so-called highway hobos. These are the stranded, sometimes mentally disturbed people who have turned the highways into their permanent or semi-permanent abode. Traveling on any highway or national road in South Africa, this is one of the visible marks of landlessness. These are people who have lost human dignity, whose lives have lost meaning. Theirs is the experience of struggling for survival, no prosperity, no meaning of life:

Land is a livelihood of survival and progress in life. Africans find meaning of life in the land. It offers and facilitates some form of dignity, integrity, and ego towards prosperity. To be robbed of the land is to be stripped of selfhood (Resane 2015b:178).

Ironically, the current scenario is one of dispossession of the land in the name of development. The cry of dispossession is still vocal and audible. Peter Delius of Witwatersrand University recently summarised this in the City Press of 24 June 2018:

We are dispossessed of our land by development and by the mines, and we get no compensation or benefits out of the so-called development of our ancestral land (2018:1).

\section{What does land mean to Africans?}

Much has been written about land in the recent past. This is exacerbated by the emotional attachment of Africans to the land. For them, to be detached from the land, is to be dehumanised. It is unfortunate that in our postcolonial and post-apartheid South Africa, whiteness remains a symbol of privilege, while blackness is a symbol of wretchedness. Symbolically, whiteness stands for landedness whereas blackness stands for landlessness (Ramantswana 2017:90). In another context, Masenya and Ramantswana (2015:98) synchronise the thought that:

One of the main visible manifestations of white privilege in South Africa is the land possession, a privilege which people of Caucasian descent continue to cling to and defend even to this day.

In some instances, this injustice was exacerbated by colonisers who were either ignorant of or disregarded the Africans' emotive relation to the land. Elsewhere I argue that "Land plays a crucial role for Africans. Land ownership is the pillar of ego, dignity, and hope upon which one's humanness relies" (Resane 2015b:176). Lucas Ledwaba, journalist of Mail and Guardian, interviewed a traditional doctor and former ANC Umkhonto weSizwe member, Mr Ephraim Mabena, and this traditionalist unequivocally declared: "The biggest humiliation you can visit upon an African is to take away his land. You can't separate us from the land. We are one with it" (2018:18). 
It is also crucial to note that Africans rarely refers to "my" land or that "the land is mine". In the African worldview land was never deemed as a personal possession but as communal property. This truth is emphasised by Ilgunas (2018:53): "In indigenous communities around the globe, personal ownership of large pieces of land was unheard of." Later, in his monograph, Ilgunas continues to elaborate that nothing convinces him that "land should ever wholly and despotically belong to one person" (2018:215).

\section{The role of the church}

I propose four approaches the church should engage in when dealing with the land issue. Inevitably, this issue is a real cry from the depth of the hearts of the majority of South African citizens. These marginalised voices have received the promise of land from the people in power, yet they are still waiting for the fulfilment of such promises (Masenya and Ramantswana 2015:97). The church cannot be detached from this real-life situation. Theology must speak to the national issues such as land, environment, human dignity, prejudices etc.

The first proposal is that of advocacy. The primary aim is to advocate strategies to clarify and entrench rights (Beinart, Delius and Hay 2017:9). This ministry is patterned after the $8^{\text {th }}$ and $9^{\text {th }}$ century BC prophets such as Micah, Isaiah and Hosea, who defended the victims of land grabbing. They exposed corruption and exploitation (Wright 2004:91). The church as a prophetic community needs to engage in a process of supporting and enabling people to express their concerns without any fear or intimidation. The church as the company of those who have been raised with Christ, is the vanguard of the new created order (Vanhoozer and Strachan 2015:109); and that order is a creation of a new community that is peacefully and strategically settled in the land where God's life, light and love is lived out in space and time (2015:151). The dispossessed must turn to the church where they can access information and services. The church community needs to demonstrate public support for or recommend a cause or policy that is not biased or prejudiced. There is a need to engage activities that aim to influence decisions within political, economic, and social systems and institutions. As advocates, the church needs to exert pressure on the government to correct this unfair or harmful situation affecting people in the community. This calls for a sympathetic ear on the ground. The settlement may be reached through persuasion, by forcing the dispossessor to buckle under pressure, by compromise, or through political or legal action. Bear in mind the kind of advocacy I propose can be confrontational, but conflict is usually a bad place to start. Good advocates know they must think hard about whether confrontation is necessary. This is one reason for careful planning of strategy and tactics. Even if the issue seems as clear as a bell, and the choice of actions seems just as obvious, it is a good idea to take another long, hard look.

Advocacy is a shared task - a task that is motivated theologically and needs to be done voluntarily (Verhoef and Rathbone 2013:99). It is an ecclesiastical task that is not enforced by a political or economic ideology or system. The advocacy proposed here is one of solidarity that is driven by love and justice, not by humanistic ideals.

Secondly, the church's role can be that of influencing bilateral agreements. This is an exchange agreement between two parties in order to give each party favourable status pertaining to certain outcomes promoted by the signatories. The agreement leads to a win-win situation. It is not a matter of $50 / 50$, but a matter of restitution whereby all 
parties are satisfied. This is a bone of contention at the moment in the political landscape where debates continue on land expropriation with or without compensation and a willing seller, willing buyer approach. The church has to be attuned to the current policies regarding land. Both the government and the people should be educated on the pros and cons of land redistribution or expropriation. The church should play an influential role by guiding and enlightening communities about what it means to occupy the land, and how to utilise the land so that food security is not at risk.

Bilateral agreements are often the outcomes of public policy and debates. Churches need to be part of these public debates, because participation in policy making entails prophetic speaking, initiating synergy toward agreements that benefit the parties at war regarding the land issue. Koopman (2010:43) applauds the role of the churches and some religious formations in collaborating on issues of public policy. It is in public spaces where theology becomes a public reality, where it becomes an open and ongoing discourse which allows for the possibility of change (Kusmierz 2016:283).

Thirdly, the church should journey with the parties involved towards consensus. This is contributing towards an amicable settlement of disputes that satisfies both parties, or where majority decisions are respected. Such consensus requires a collective opinion middle ground in decision making, between total assent and total disagreement. The church as a community of faith should play a paracletic role of prodding people towards a desired achievement. The church is the love of Christ incarnate:

We do not proclaim from the distance, from the security of some haven of selfrighteousness, but that we come very close to the people we are inviting, in relating to them in solidarity because we are as much in need of the good news as they are (Kritzinger et al 1994:143).

The church in society is the mouthpiece of Christ, and an agent of peace. This implies missiological incarnation par excellence. The church is in eschatological journey as a missional channel in the hurting world. Through proclamation, it brings liberation to the oppressed and the marginalised societies where Christ does not rule supreme. This is not the conveyance of human intellect or eloquence. We all agree that land reform is a complex web that cannot be limited to a narrow political approach of land expropriation, nor to the economic argument that ignores the country's brutal political history. Jason Musyoka of City Press is correct that the process involves a complex tapestry, woven from competing political, economic and social imperatives (2018:3). Regardless of this delicate imbalance, consensus must be reached in order to defuse the ticking time bomb ready to explode should delay drag on any longer. As part of theological responsibility, church theology must be understood as "public ethical theology because of its involvement and continued evolution in light of pressing world dilemmas" (Chung 2017:153).

Fourthly the church can play the critical role of being part of or the facilitator of dialogue regarding land. A theology of dialogue or dialogical theology requires introspective reflection where self-examination is deliberated to assess standing relationships with another view that may differ from one's own standpoint. Kasper (2004:35) speaks of dialogical philosophy that ends monological thinking, and contributes immensely to understanding this dialogical philosophy as: 
I don't be without thou; we don't exist for ourselves; we exist with and for each other; we do not only have encounter, we are encounter, we are dialogue.

I explain the same notion elsewhere:

Dialogues often take the form of theological consultations, which highlight differences and seek ways of coming closer together through new understandings, reinterpretation or correction of misunderstandings, and healing of divisions. The process of discussion itself brings people closer together and helps to break down barriers in social spaces, necessitating the need for social scientists' interventions (Resane 2018:4).

Dialogical tasks are carried out transparently regardless of dialogical partners' differences regarding their personalities, convictions, and/or predispositions. The participants have different personalities and dialoguing may include some dissenting ideas. It is true that:

Dialogue makes participants more sympathetic to one another, even when they disagree, and assists enormously in preparing the ground for negotiation or decision-making on emotion-laden issues (Resane 2017:204).

Consensus and mutual understanding are the goals of dialogue. The dissenting parties around the table synergise towards a unified action in order to address the situation; or clarify any misunderstanding. In theological dialogue, fragmentations, misunderstandings, and misinformation are all addressed because:

Dialogue is a special kind of discourse that enables people with different perspectives and worldviews to work together to dispel mistrust and create a climate of good faith (Resane 2016:62).

Dialogue minimises prejudice, stereotypes, and inhibitions. Theology has and is always at the centre of dialogical tasks to bring harmony, peace, synergy, and stability during civil unrest. This is done both internally (ecclesiastically) and externally with other churches and communities, with other religions, and also with modern culture, arts and science, politics and media (Kasper 2004:176). It is a sensible endeavour to dialogue with those holding different worldviews and perspectives. "A dialogue makes sense simply because we have different experiences and concerns" (Holter 2009:77). Participation in land debates is not about revenge or narrow nationalism. Chris Maxon wrote in the City Press of 3 June 2018:

We need to assert that the commitment to land reform is also to assert the people's identity and because it is a symbol of citizenship (2018:3).

I concur with Verhoef and Rathbone (2015:156) that this land debate needs the development of the encompassing ontological nature of land and possibility of justice. Debates need to be theological without any bias or prejudice. What God says about the 
land should take precedence over emotive reactions. This ontology should include the diversity of ontological dimensions of land to address injustices. Mabena, whom I referred to above, continues that he fears that:

The burning issue of land could lead to violence and bloodshed if not handled properly and needs to be resolved through dialogue (2018:18).

This is the space and time when church dialogues become grounded in communicative rationality and the reason for anamnesis in remembrance of the reality of innocent victims and mass suffering (Chung 2017:158) of the land-dispossessed masses in our society. Ethics should come to the fore and articulate the value of life in the midst of tensions and conflicts. As a norm, dialogue should be a conversation from within the polyphony of voices that constitute the Christian community (Thiemann 1991:135). The church cannot proclaim from a distance, but should stand in the context in order to empathise with victims. The dialogue should reimagine the land debate on the biblical principle that "the land was intended to be equitably shared out, so that every household had its part in the national inheritance" (Wright 2004:90).

\section{Conclusion}

This paper points out that the church has a critical role to play in current land debates in South Africa. Church docility in national matters such as land expropriation is anathema, and cannot be tolerated even a fortiori (with strong reason). Ecclesiastical community is the salt of the earth, and one of the ways of giving taste to the world, is through its clemency. In this national crisis, Bouyer (2013:227) rightly points out that:

So long as there are Christians in the world, they must open their hearts to the sufferings and needs of others, and they must spend themselves personally for others, showing by their deeds that they think of their goods and only their own property, but as that of other people as well.

The preaching of love without self-immersion into addressing ólethros (corruption), is hypocrisy. It is in the spirit of advocacy that the church must assimilate canonical commands. It is, after all, about Te totum applica ad texttum, rem totam applica ad te (Applying yourself wholly to the text, and applying its matter wholly to yourself). It is in the spirit of contributing towards bilateral agreements between the landed and the landless, that the church can proudly testify to mirabilia Dei (the wonderful deeds of God). The church cannot work towards consensus between the perpetrators and the victims of land injustice, unless the church vehemently stands the ground of video, sitio, volo (I see, I thirst, I will). As justice is mercilessly brutalised, the church thirsts for righteousness, and theo-determinedly takes decisive steps to restore justice. The church should be determined to have justice restored, but "not without reminding ourselves unwearyingly that it is God, in whose presence we are" (Bouyer 2013:115), who, through his word, commands us to be the agent of human dignity restoration. This is creating in us both the willing and the doing initiative that is inevitable and mandatory for the church's mission in a hurting world. In dialogue, the partners are directed by the visible word, where love, understanding, and humility characterise the dialogical processes. 
Paternalistic positions and approaches to dialogue cannot be welcomed. Dialogue is collaboration of equal partners where perpetrators and victims enter transparent spaces to walk together in the light. When the Word guides, there will be self-control (enkrateia) and understanding (synesis ).

The role of the church in this national crisis is beyond dispute. The church has a theological mandate to demonstrate and incarnate the love of Christ:

The role of ekklesia is therefore to proclaim the gospel of the kingdom. The ekklesia belongs to the present aeon and therefore has to challenge social injustices prevalent in the cosmos. Its presence in this age necessitates the proclamation of the truth; hence ekklesia will always be in conflict with everything opposed to the truth, because the truth is existentially in combat with evil (Resane 2015a:5).

If these suggested roles are followed, despite the fact that Africans were violently dispossessed of the land, the national law will be in place to "create the conditions necessary for coexistence and a shared prosperity among the races" (Ngcukaitobi 2018:73). The dictum remains and the church mandate still echoes: From the land we were born, lived, and shall return. Human dignity is intertwined with the land, therefore the church is a syzygus (yokefellow/partner) for promoting this dignity.

\section{BIBLIOGRAPHY}

Beinart, W., Delius, P. and Hay, M. 2017. Rights to land: A guide to tenure upgrading and restitution in South Africa. Auckland Park: Fanele, (Jacana Media).

Bouyer, L. 2013. Introduction to the spiritual life. Notre Dame: Christian Classics.

Changuion, L. and Steenkamp, B. 2012. Disputed land: The historical development of the South African land issue, 1652-2011. Pretoria: Protea.

Chung, P.S. 2017. Postcolonial public theology: Faith, scientific rationality, and prophetic dialogue. Cambridge: James Clarke \& Co.

Delius, P. 2018. The chief problem with land rights, The City Press, 24 June 2018.

Holter, K. 2009. Does a dialogue between Africa and Europe make sense? In De Wit, H. and West, G.O, Africa and European readers of the Bible in dialogue. Pietermaritzburg: Cluster Publications, 69-80.

Ilgunas, K. 2018. This land is our land: How we lost the right to roam and how to take it back. New York: Plume (Penguin Random House).

Kasper, W. 2004. That they may be one: The call to unity. London: Burns \& Oates.

Koopman, N. 2010. Churches and public policy discourses in South Africa, Journal of Theology for Southern Africa 136 (March 2010): 41-56.

Kritzinger J.J., Meiring, P.G.J and Saayman, W.A. 1994. On Being Witnesses. Halfway House: Orion Publishers.

Kusmierz, K. 2016. Theology in transition: Public theologies in post-apartheid South Africa. Zurich: Lit Verlag.

Ledwaba, L. 2018. Healing resurrects blighted land above Mamelodi, Mail \& Guardian, 29 March to 5 April 2018. 
Masenya, M. and Ramantswana, H. 2015. Lupfumo lu mavuni (Wealth is the land): In search of the Promised Land (cf. Exod. 3-4) in the post-colonial, post-apartheid South Africa, Journal of Theology for Southern Africa 151 (March 2015): 96-116.

Maxon, C. 2018. Land: Are we there yet? City Press, 3 June 2018.

Mbatha, N.C., 2017, How to understand, evaluate and influence efficient progress in South Africa's land reform process: A typology from historical lessons from selected sub-Saharan African countries, South African Journal of Economic and Management Sciences 20(1). Online: https://doi. org/10.4102/sajems. v20i1.1990 (Accessed: 16 March 2018)

Mofokeng, T. 1997. Land is our mother: A black theology of land. In Guma, M. (ed.), An African challenge to the Church in the $21^{\text {st }}$ century. Cape Town: Salty Print, 45-56.

Musyoka, J. 2018. The complex path to land reform, City Press, 11 March 2018.

Ngcukaitobi, T. 2018. The land is ours: South Africa's first black lawyers and the birth of constitutionalism. Cape Town: Penguin Books.

Ramantswana, H. 2017. Decolonial reflection on the landlessness of the Levites, Journal of Theology for Southern Africa 158 (July 2017): 72-91.

Resane, K.T. 2015a. The mining-induced displacement and resettlement: The church as a leaven and ecclesiology in context's response, HTS Teologiese Studies/ Theological Studies 71(3), Art. \#2967, 8 pages. Online: http:// dx.doi.org/10.4102/hts. v71i3.2967 (Accessed: 28 July 2016)

Resane, K.T. 2015b. Naboth's vineyard: Theological lessons for the South African land issue, Acta Theologica 2015 35(1): 174-188.

2016. Africanising a theological discipline: Paradigm shifts for the new trends. In Venter, R. (ed.), Theology and the (post) apartheid condition: Genealogies and future directions. Bloemfontein: Sun Press, 50-57.

2017. Communion Ecclesiology in a racially polarised South Africa. Bloemfontein: Sun Media.

2018. Transparent theological dialogue - "Moseka Phofu Ya Gaabo Ga a Tshabe Go Swa Lentswe” (A Setswana proverb), Religions 2018, 9(2): 54. Online: https://doi.org/10.3390/re19020054 (Accessed: 16 November, 2017)

Thiemann, R.F. 1991. Constructing a public theology: The church in a pluralistic culture. Louisville: Westminster John Knox Press.

Vanhoozer, K.J. and Strachan, O. 2015. The pastor as public theologian: Reclaiming a lost vision. Grand Rapids: Baker Academic.

Vellem, V. 2016. Epistemological dialogue as prophetic: A black theological perspective on the land issue, Scriptura 115 (2016:1): 1-11.

Verhoef, A.H. and Rathbone, M. 2013. Economic justice and prophetic discourse in the South African context - Towards a dialogical mode of discourse, Journal of Theology for Southern Africa 145 (March 2013): 92-109.

2015. A theologically informed ontology of land in the context of South African land redistribution, Journal of Theology for Southern Africa 152 (July 2015): $156-170$.

Wright, C.J.H. 2004. Old Testament ethics for the people of God. Downers Grove: IVP Academic. 